\title{
MYTHOLOGICAL TOPICS ABOUT GRIPHONS AND THEIR EPIC INTERPRETATIONS IN UZBEK FOLKLORE
}

\section{Tukhtamurod Olimovich Kuchkarov}

Associate Professor Jizzakh Branch Of The National University Of Uzbekistan

\section{ABSTRACT}

Sounds of ancient mythological imagination and archaic picture about the geophones are analyzed in the article which have stored in reflection form in Uzbek folk-lore. It was proved on the basis of comparative analyze of folk-lore, archeological and linguistic materials that the historical-genetic sources of dimorph images are bond up with archaic astrological idols of ancient people in the Central Asia.

KEYWORDS: - Mythology, astrological symbols, mythological image, geophone, mythological picture, mythological legend, Uzbek folk-lore, tale, dimorphs image, mythological imagination.

\section{INTRODUCTION}

In the ancient mythology of the peoples of Central Asia, the mythical image of winged animals was widespread, where the wings served as a detail, an astral symbol indicating belonging to the higher world, to the sky. Therefore, the image of such winged animals indicated their divinity, super naturalness. One of these mythological images is the griffin. The griffin was portrayed as a fantastic creature (monster), which integrally embodied the features inherent in an animal and a bird. In the "Mythological Dictionary", the word "vulture" is interpreted as "a mythical beast, with the body of a lion and the head of an eagle." [1] In the "RussianUzbek Dictionary" "the neck is mythical. 1. A huge, winged beast (monster) with the body of a lion and with a lion's or eagle's head. 2. Black bird kite". [2.222] The image of the griffin was a traditional character in the mythology of the peoples of Central Asia, Ancient Egypt, Greece and Turkey [3].

In ancient mythology, there were two types of this dimorphic image of the beast-bird, i.e. lion-griffin or winged lion and eagle - griffin or winged beast with the head of a bird of prey [4]. The image of the griffin embodied the features inherent in the beast and the bird, where the beast personifies the universe, the earth; and the features of a bird is a symbol of the sky, heavenly. As L.I. Albaum noted, 
CURRENT RESEARCH JOURNAL OF PHILOLOGICAL SCIENCES 2(12):

56-61, December 2021

DOI: https://doi.org/10.37547/philological-crjps-02-12-12

ISSN 2767-3758

(C)2021 Master Journals

Crossref do

gil Google

Accepted08th December, 2021 \& Published $13^{\text {th }}$ December, 2021

"it is difficult to say when and where images of griffins first appeared, but by the middle of the first millennium BC. NS. this story is widely known to the most diverse peoples of the world. Perhaps they originated in ancient times along with the appearance of petroglyphs of animals, sometimes patrons, they were endowed with a complex of attributes characteristic of various animals" [5].

The genetic origins of the image of the griffin are directly related to the dualistic views on the struggle of good forces with evil creatures, therefore, according to the ideas of the ancient herders, this mythical creature supposedly protects livestock and people from evil forces. This image "is one of the personifications of nature, with its inherent dualism of the forces of good and evil. Maybe the struggle of animals with griffins in the world of early nomads had the idea of a struggle between light and darkness. This cosmic idea grew out of totem ideas, but it was higher than them, for it transferred the images of tribal cults to the plane of cosmic forces and ideas about the good and evil forces of nature" [6].

\section{THE MAIN FINDINGS AND RESULTS}

In the process of the development of archaic mythology, on the basis of the dualistic nature of the cosmic essence of this image, dimorphic images of a griffin arose. Many images of a griffin or a mythical creature with the head of an animal and the body of a bird were found during archaeological excavations in Central Asia [7]. Professor S.P. Tolstov notes that on a fragment of a flask found under the central house of the Kuikirilgan-kal'a fortress, more precisely, at the entrance from the eastern side, there is an image of a huge griffin. Blue ceramic rhytons, found in 1952, also contain relief images of griffins and horses [8]. And on a ceramic fragment found by archaeologists in Kalalikir, a griffin with an eagle's head, with large eyes and a slightly open beak was depicted [9].

The image of a griffin became widespread in the era of the Kushans and in the art of the Middle Ages. This mythical image was depicted on dishes, seals and silk fabrics. A wooden vessel with the image of a griffin was found in Panjikent. And on the wall paintings of one of the monuments of Samarkand, a circle of griffins in the form of winged lions is depicted. In Varakhsha, in the "hall of white elephants", griffins in the form of an eagle are also depicted on the wall [10].

On the walls of the "Red Hall", opened as a result of archaeological excavations of the ruins of Varakhsha, an image of white griffins (with a dog's body) attacking an elephant was found. VA Shishkin believes that this mythical image is a "dog-like vulture" and notes that this ancient image was presented as a symbol of the sun [11]. We believe that the image of a griffin depicted in the "red hall" of Varakhsha, in essence, resembles the image of a mythological animal [12] found in the village of Tomiz in the Glazovsky district of Russia. This image also helps to reveal the essence of the legend of the ancient Greek historian Philostratus, who wrote that" by flapping the wings of vultures can defeat even elephants and dragons."

After cleaning the southern wall of the "Red Hall", fragmentary remains of the tormenting scene were found, on which traces of images of the lower parts of the torso of two mythical creatures were preserved. The front legs of one creature resemble a bird's legs, and the hind legs resemble a dog-like shape. According to V.I.Shishkin, "one of the varieties of a vulture with a lion's body and an eagle's head was depicted here. This is a very ancient image - a symbol of the sun, the image of which from a seal from Susa dates back to the $3 \mathrm{rd}$ millennium BC" [13]. 
CURRENT RESEARCH JOURNAL OF PHILOLOGICAL SCIENCES 2(12):

56-61, December 2021

DOI: https://doi.org/10.37547/philological-crjps-02-12-12

ISSN 2767-3758

(C)2021 Master Journals

Crossref do



Accepted08th December, 2021 \& Published $13^{\text {th }}$ December, 2021

Although the forelegs of the griffin from the Suzi seal are depicted as bird legs, the hind legs resemble lion's legs, and the bird-like head is surrounded by long manes. Based on this, it can be stated that a griffin with a lion's carcass is depicted in the Suz print. And in the battle scene, found in the southern wall of the "Red Hall" of Varakhsha, a griffin with the body of a dog is depicted. In our opinion, numerous images of a griffin in the ancient and medieval art of Central Asia arose on the basis of mythological stories and legends of our distant ancestors. The creators of the wall paintings of ancient Varakhsha knew well the legends about the battles of vultures with elephant riders, therefore, in the creative process, they used epic subjects that were widespread in the Zerafshan oasis.

In ancient written sources, there are legends about a mythical creature in the form of a beast-bird. In particular, in the ancient Chinese chronicle "Hanshu" it is written: "The population living in the Tyachzhi region grows up large and small birds that give milk like lions, karkidons, cows. The eggs of these birds are like a jug. During the Gonyuan reign (AD 101), in the 13th year of the reign of Emperor Hedi, King Anxi Manqui presented the Chinese palace with lions and large birds. Then these birds were named "Anxi Birds". According to Guan-Zhi: "It was a Zhi-in bird, the legs and body of which were a camel, green in color, their height reached 89 feet with a raised head, and a wingspan of over 10 feet. The bird ate barley and laid eggs like a jug. [14] " Bearing in mind that the toponym "Tyaozhi", given in this legend, is the name of an ancient mountainous region, i.e. the name of one of the regions of the Fergana Valley, it can be stated that the image of the griffin is genetically related to the ancient mythology of the peoples of Central Asia.

Herodotus, in the fourth part of the History, based on the stories of the Issedons, writes: "beyond the land of the bald" live "one-eyed people and vultures guarding the gold of the Scythians" [15]. In the works of the Greek writer Aeschylus (5th century $\mathrm{BC})$, the griffin was depicted as a "dog-bird". Aeschylus notes that in the places where the "oneeyed horsemen of the Arimasps" live "the sharpbilled mute dogs of Zeus" [16] also live. This detail indicates that, in the work of Aeschylus, a winged dog with an eagle beak is depicted.

The ancient Greek scientist Ctesias (IV-V century $\mathrm{BC}$ ) in his book "Indica", telling the legend about the griffins of the ancient Bactrians, writes: moreover, also similar to the claws of a lion. They say that his back is covered with feathers and the color of these feathers is black, and in the front, they say, is red. His wings are neither one nor the other color, but white. His neck is decorated with dark blue feathers, his eyes are said to be fiery. Nests are in the mountains. It is impossible to catch an adult vulture, so they catch chicks. The Bactrians, neighboring with the Indians, say that the vultures in those places are the guardians of gold" [17.

The plot of this legend was widely known among the Bactrians, because archaeological finds found in southern Uzbekistan indicate the presence of the image of a griffin in the form of a dog in the mythology of the Bactrians. In particular, the griffin is depicted in a silver statuette (III-II century BC), which is kept in the British Museum. This griffin has the body of a dog, the tail is wrapped in a circle, in the place where the front paws are connected to the body, wings have grown, there is a mane on the neck, like a horse's, the head is similar to that of a $\mathrm{dog}$, and a horn protruding forward has grown between the ears.

Based on the image of a griffin from a seal belonging to the II-millennium BC. BC, found by A. Askarov during the research of Sapallitepa, which is located on the territory of ancient Northern Bactria, it can be concluded that this image was widely known in 
CURRENT RESEARCH JOURNAL OF PHILOLOGICAL SCIENCES 2(12):

56-61, December 2021

DOI: https://doi.org/10.37547/philological-crjps-02-12-12

ISSN 2767-3758

(C)2021 Master Journals

Crossref do

81 Google

Accepted08th December, 2021 \& Published $13^{\text {th }}$ December, 2021

mythology and art as early as the Bronze Age. According to G.A. Pugachenkova [18], a griffin in the form of a winged dog is also depicted on a carnelian found near Termez. In the Fayaz Tepe hills near the city of Termez, where archaeological research has been carried out since the 30s of the twentieth century, during excavations carried out in 19681976, remains were found - the remains of an ancient Buddha temple dating back to the 1st-3rd centuries AD. NS. Among the finds found in this temple, of particular importance are statues of Buddha sitting under the sacred bodhi tree and a painted stone block, which depicts a griffin with its head turned to the right [19]. These findings indicate that among the population of ancient Bactria there were mythological views about a winged beast with the body of a dog. The story of the gold they protected was also widespread in the oral folk art of the Bactrians.

In ancient Greek mythology, the griffin was depicted as a half-bird, half-lion. According to her, griffins live on the mountain, which is located near the edge of the Arimasp and guard the gold. Therefore, because of this wealth, the Arimasps constantly fought with the griffins. In the mythology of the Arimaspians, it is said that every day in the morning that the sun god drives around the sky in a golden chariot drawn by griffins [20].

Another ancient mythological legend belongs to the Greek historian Aristeus (7th century BC). According to the story of Aristeas, griffins "live in the far north, near the Ripaean mountains, from which the snow never melts and where Boreas blows, the north wind [21.21].

The land there produces gold in abundance, and vultures guard it. The Arimasps who live next to them steal gold and constantly fight for it with vultures".
Aristeus says that he heard this legend while traveling to the land of the Issedons, who live beyond Mount Ripey. The historian IV Pyankov, based on the assumptions of some scientists, suggests that "Ripeyskie mountains" are the Altai mountains, and the phrase "Issedonians' residence" means steppe or steppe forests beyond the Ural mountains [21. 21]. Herodotus believes that the land of the Issedons is located "on the side of the rising sun of the hairless" and "on the eastern bank of the Araks (Amu) river", i.e. this is the territory of the present Kyzylkum. According to Herodotus, "opposite the Issedons - towards the sunrise across the Araks River, a large and brave tribe of Massagets live. They are considered a Scythian tribe " [22]. These data show that archaic myths and legends about griffins arose in the oral folk art of the ancient inhabitants of Central Asia and prove the incorrectness of IV Pyankov's hypothesis that "mythological ideas about vultures are a product of ancient mythology" [21.21].

According to A.P. Zoporozhenko and D.V. Cheremisin, who studied the history of the origin of the legend about the battle of the Arimasps with the griffins, this plot arose at the basis of the ancient Indian-European mythologeme about the hero's journey to another world, i.e. into the world of the dead. According to archaic myths, between the two worlds, there is a "paradise" in which the keepers of the riches of the world of the dead live - such as one-eyed, noseless people, dragons, etc.

Therefore, only mythical birds that can fight and defeat these guardians can enter this world. In the "Scythian version" of this plot, griffins are turned into guardians of gold [23].

We agree with the scientific version that the plot of the legend about the gold of vultures arose on the basis of mythological beliefs about another world. The dog-like griffin, Semurg, preserved in Uzbek 
CURRENT RESEARCH JOURNAL OF PHILOLOGICAL SCIENCES 2(12):

56-61, December 2021

DOI: https://doi.org/10.37547/philological-crjps-02-12-12

ISSN 2767-3758

(C)2021 Master Journals

Crossref do



Accepted08 ${ }^{\text {th }}$ December, 2021 \& Published $13^{\text {th }}$ December, 2021

folklore, serves as a guide between the two worlds, i.e. helps the hero get out of the bowels of the earth into the light of day.

Therefore, we think that the legend of the griffins first appeared in the oral folk art of the peoples living in the territory of Central Asia. Moreover, the mythological ideas about vultures guarding gold have survived in Uzbek folklore [24]. In an Uzbek folk tale, recorded by the ethnographer G.P. Snesarev, it is said that once a rich man hired a poor Zhigit to work, on the condition that he would feed him for 39 days, and the Zhigit had to work only one day. On the appointed day, the rich man sews a sack of ox hide and, having thrust the poor man into the sack, sews it up. After that, a huge bird arrives and takes the bag with the guy to the top of the mountain. The bird pecks at the bag, but when it sees the guy it flies away. And the guy coming out of the bag sees that there is a lot of gold and precious stones around.

And in the Uzbek folk tale "Khoja Bozirgon and Drovasek Khasan" it is said that the old man fed the boy for 39 days, and on the fortieth day he killed the bull and sewed a waterskin out of his skin and asked the boy to climb into the waterskin and see if there were any holes. When the boy got into the wineskin, he tied the end of the wineskin tightly. Brought this wineskin downhill. After some time, a huge eagle appears and carries the wineskin into the sky. Having reached the top of the mountain, the wineskin falls from the bird's nails. When the waterskin falls, it bursts and the boy comes out into the light [25].

He sees large bars of gold under his feet. Professor Zh.Yusupov correctly notes that "mythological stories about mythical birds guarding treasures belong to the folklore of the peoples of Central Asia".

\section{Conclusion}

This indicates that the tale arose on the basis of the mythological plot about the gold of vultures among the ancient Bactrians. Although, as noted by Philostratus, "these creatures were offered to the sun." The image of a griffin or dog-bird is an archaic character in Uzbek mythology. Therefore, myths and legends about flying dogs or dogs hatched from a bird's egg have survived to this day in the folklore of the peoples of Central Asia.

\section{ReFERENCES}

1. Mythological dictionary. Moscow: 1965. P.79.

2. Russian-Uzbek dictionary. 1-volume. Tashkent: 1983. - p. 222.

3. Akalin L. Turkish folklore courses. - Ankara, 1993. -p. 140.

4. Rempel L.I. Age-old images and wandering subjects in the traditional art of Central Asia. Tashkent: 1987. -p. 40-42.

5. Albaum L.I. Griffin from Fayaz-Tepe // History and Archeology of Central Asia. Ashgabat: Ylym, 1978. -p. 63.

6. Rempel L.I. Decree. lit. - p.42.

7. Masson M.E. Settlements of Old Termez and their study // Proceedings of the UzFAN SSR. Ser. 1. Issue 2. - Tashkent, 1941. - p. 46 (fig. 19-21); Shishkin V.A. Architectural decoration of the palace in Varakhsha // Proceedings of the Eastern Department of the State Hermitage. T.4. - L., 1947. - P.254 (tab. 2); Tolstov S.P. Results of twenty years of work of the Khorezm archaeological and ethnographic expedition (1937-1956) // Soviet Ethnography. Moscow: 1957. - No. 4. p.49 (fig. 15).

8. Tolstov S.P. In the footsteps of the ancient Khorezm civilization. Tashkent, 1964. - p. 
307.

9. Tolstov S.P. The results of the archaeological and ethnographic expedition of the Academy of Sciences of the USSR in 1953 // Questions of ancient history. Moscow: 1955. - No. 1. - p. 198.

10. Rempel L.I. Decree. lit. - P.42.

11. Shishkin V.A. Varakhsha. Moscow: 1963 .-- p. 153.

12. Orbeli I.A., Trever K.V. Sassanian metal. Moscow: 1935. - Table 22.

13. Shishkin V.I. Decree lit. - p. 157.

14. N. V. Kyuner Chinese news of the peoples. - M .: Nauka, 1961. - P.109.

15. Ancient authors about Central Asia. Tashkent, 1940 .-- p. 20.

16. P'yankov I.V. Bactrian vulture in ancient literature // History and culture of the peoples of Central Asia (antiquity and the Middle Ages). Moscow: 1976 .-- p. 22.

17. P'yankov I.V. Decree article. - p.19.

18. Pugachenkova G.A. Griffin in the ancient and medieval art of Central Asia // Soviet archeology. Moscow: 1959. - No. 2. - P.73, 78.

19. Albaum L.I. Griffin from Fayaz-Tepe. - p. 6062.

20. Leach M. Standart dictionary of Folklore, Mythology and Legend. 1. - N. York, 1949. P.467.

21. P'yankov I.V. Decree. article. - p.21.

22. Herodotus. History. Book 1. Moscow: 1957 .-p. 325.

23. A. V. Zaporozhenko, D. V. Cheremisin Arimaspes and vultures: pictorial tradition and Indo-European parallels // Siberian archaeological review. - 2002. Issue 6. ("Hol @ mail. Archeology. Nsc.ru").

24. Snesarev G.P. Khorezm legends as a source on the history of religious cults in Central Asia. Moscow: 1983. - p. 152.

25. Yusupov J. The fairy tale of Khorezm and the reality of life. - Tashkent, 1997. - P.87. 